Bulletin of Pharmaceutical Sciences
Assiut University
Website: http://bpsa.journals.ekb.eg/
e-mail: bullpharm@aun.edu.eg

\title{
ANTI-INFLAMMATORY ACTIVITY OF THE FOOD PLANT CALLIGONUM POLYGONOIDES L. FLAVONOIDS TARGETING NF-кB
}

\author{
Ahmed M. Zaher, Mai A. M. Ahmed and Nesma M. Mohamed \\ Department of Pharmacognosy, Faculty of Pharmacy, Assiut University, Assiut 71526, Egypt
}

\begin{abstract}
Calligonum polygonoides L. subsp. comosum (Polygonaceae) is a wild shrub that grows on the sandy deserts of various regions in North Africa, Western Asia and Southern Europe. In some of Asian countries, the flower buds and young branches of the plant are used to prepare traditional food dishes. Also, different organs of C. polygonoides L. are used traditionally in treatment of stomach diseases. The isolation of anti-inflammatory lead compounds was performed by using different normal silica gel, reversed phase C-18, and sephadex LH-20 open columns. The identification of the isolated compounds was done using NMR spectral techniques. The isolated compounds are of different flavonoid classes; two flavonol glycosides; kaempferol-3-O- $\beta$-D-glucuronide and mequilianin, one flavan-3-ol; catechin, and one dihydroflavonol; taxifolin. The methanol extract and ethyl acetate fraction of Calligonum polygonoides L. subsp. comosum exhibited anti-inflammatory activity against $N F-\kappa B$ translocation pathway on HEK293 cells. All of them were active against $N F-\kappa B$ translocation, and previously isolated from the plant under study. Kaempferol-3-O- $\beta$-D-glucuronide, a flavonoid glycoside demonstrated the most potent $N F-\kappa B$ inhibition in comparing with other flavonoids; taxifolin, catechin, and mequilianin. Therefore, the food plant aerial parts of $C$. polygonoides are rich in nutraceuticals (flavonoids and flavonoid glycosides) that can be utilized in the treatment of vascular inflammation.
\end{abstract}

\section{INTRODUCTION}

Calligonum polygonoides L. subsp. comosum is a wild shrub that belongs to family Polygonaceae; it grows on the sandy deserts of tropical regions in North Africa, Western Asia and Southern Europe ${ }^{1}$. The flower buds and young branches of the plant are used to prepare some traditional food dishes in some Asian countries ${ }^{1}$. The fresh flowers are edible as sugars and nitrogenous constituents rich bread ${ }^{1}$. The plant fruits also are used as fodder for cattles $^{2}$. The plant aerial parts are used for treatment of stomach disorders and toothaches in folk medicine ${ }^{3}$. Additionally, the flowers are traditionally used for cough, cold, and asthma and shoot latex is applied topically to help in healing of dog bites, scorpion tingle and eczema ${ }^{4}$.

Previously reported biological studies on the aerial parts of the plant extracts demonstrated protective activity in oxidative stress $^{5}, \quad$ antiosteoporotic ${ }^{6}, \quad$ anti-ulcer $^{7}$, hypoglycaemic ${ }^{8}$, cytotoxicity, and antioxidant activities $^{3}$. The enzymes inhibition activities of different $C$. polygonoides extracts against amylase, tyrosinase, and acetylcholinesterase enzymes have been reported as well ${ }^{4}$. The preliminary phytochemical screening study in the seeds, buds, stems, and flowers extracts resulted in detection of flavonoids at all plant parts, in addition to alkaloids, terpenoids, steroids, carbohydrates, and phenols in seeds, buds and flowers ${ }^{9}$. High level of proteins has been detected in seeds and flowers only ${ }^{9}$. Several flavonoids such as kaempferol, quercetin, kaempferol-3-O-rhamnopyranoside, quercitrin, isoquercitrin, kaempferol-3Oglucuronide, quercetin-3-O-glucuronide, procyanidines, kaempferol-3-O- $\beta$-D-(6"-n-butyl glucuronide), taxifolin, (+)-catechin, dehydrodicatechin were previously isolated from the aerial parts of $C$. polygonoides ${ }^{3}$. 
On the light of the valuable nutritional and biological importance of $C$. polygonoides, our study reports new biological assessment of the aerial parts extracts and isolated flavonoids in vascular inflammation through the inhibition of NF- $\kappa$ B pathway translocation, and hence inhibition of inflammatory mediator's release. Vascular inflammation is the common cause of many vascular diseases as atherosclerosis, myocardial infarction, and congestive heart failure $^{10}$. The inhibition of NF-kB pathway has been established to display valuable impact in the treatment of various cardiovascular diseases as hypertension ${ }^{11}$, myocardial infraction $^{12}$, and arteriosclerosi $^{13}$. These findings support the idea of the inhibition of $\mathrm{NF}-\kappa \mathrm{B}$ as a promising strategy in minimizing cardiovascular diseases.

Alzheimer's disease, a chronic neuroinflammation in which the levels of proinflammatory mediators; cytokines, interleukins, interferons, chemokines, and tumor necrosis are elevated in the brains ${ }^{14}$. Hence, the possibility of inhibiting or delaying the onset of Alzheimer's disease can be accomplished through the inhibition of NF- $\mathrm{KB}$ activation ${ }^{15}$.

However, the anti-inflammatory effects of some flavonoids such as quercetin, luteolin, kaempferol, fisetin, apigenin, isoliquiritigenin, chrysin, rutin, genistein, kaempferol, and silymarin through the modulation of NF- $\mathrm{KB}$ translocation were previously reported ${ }^{16}$, our study reveals the activity of flavonoid glycosides; kaempferol-3-O-glucuronoide (1) and mequilianin (4) as new potent inhibitors of $\mathrm{NF}-\kappa \mathrm{B}$ activation pathway.

\section{MATERIAL AND METHODS}

\section{Plant material collection and extraction}

C. polligonoides is a wild shrub that grows in Al-Wadi Al-Ebrahimi, Assiut Governorate, Eastern desert of Egypt. The aerial parts of $C$. polligonoides were collected in April 2019, from its wild natural habitat. The plant is not considered as rare species, hence, no permission was mandatory from Assiut Governorate for collection the plant samples. The collected plant samples were then identified by Dr. Ahmed M. Fareed, Associate professor of plant taxonomy, Department of Botany, Faculty of Science, Assuit university, Assiut, Egypt. The dried sample of $C$. polligonoides was deposited at the Herbarium of Department of Botany, Faculty of Science, Assuit University with voucher number 1722015. The remaining fresh aerial parts of the plant were air-dried at room temperature, and then powdered and weighed to obtain 2.5 $\mathrm{kg}$ dried powders. The dried plant powder (2.5 $\mathrm{kg}$ ) was extracted by maceration in $5 \mathrm{~L}$ methanol (70\%) with gentle shaking using shaker (Selecta, Kiev, Ukraine), then filtered every $48 \mathrm{hr}$. The extraction process was repeated three times and the combined methanol extracts were concentrated by Rota vapor (Buchi RII, Essen, Germany). The dried methanol extract $(250 \mathrm{~g})$ was kept in refrigerator till isolation of bioactive compounds.

\section{Isolation of compounds 1-4}

The potent anti-inflammatory ethyl acetate fraction was conducted to the open glass column $(75 \mathrm{~mm} \times 600 \mathrm{~mm})$ prepacked with 400 g silica gel (Silica gel 60, 0.015-0.040 mm). The mobile phase used in chromatography were consisted of solvent A (dichloromethane) and solvent $\mathrm{B}$ (methanol). The solvents were eluted in a gradient concentration (0\% -100\% methanol). The effluent was collected in a 200 $\mathrm{ml}$ flasks and monitored on TLC under UV lamp, and after spraying with sulphuric acid $10 \%$. Four main sub-fractions (I, II, III, and IV) were obtained. Four flavonoids 1-4 were isolated from sub-fractions (I-IV) by using open columns packed with different adsorbents. Silica gel G60 (60-120 mesh, Merck, Darmstadt, Germany) was used as packing material in open column chromatography. Sephadex LH-20 (Mitsubishi Kagaku, Tokyo, Japan) was utilized as packing material for molecular sieving in column chromatography. Nuclear magnetic resonance (NMR) spectra including 1D- $\left({ }^{1} \mathrm{H}-\mathrm{NMR}\right.$ and ${ }^{13} \mathrm{C}$-NMR) of the isolated compounds were recorded on Bruker Avance DRX spectrometer at $400 \mathrm{MHz}\left({ }^{1} \mathrm{H}\right)$ and $100 \mathrm{MHz}\left({ }^{13} \mathrm{C}\right)$.

\section{Characterization of isolated compounds 1-4}

Kaempferol-3-O-glucuronide (1). Yellow amorphous powder. ${ }^{1} \mathrm{H}-\mathrm{NMR} \quad(400 \mathrm{MHz}$, $\left.\mathrm{CD}_{3} \mathrm{OD}\right): \delta 8.10\left(2 \mathrm{H}, \mathrm{d}, J=8 \mathrm{~Hz}, \mathrm{H}-2^{\prime}, \mathrm{H}^{-} 6^{\prime}\right) ; \delta$ $6.90\left(2 \mathrm{H}, \mathrm{d}, J=8 \mathrm{~Hz}, \mathrm{H}-3^{\prime}, \mathrm{H}-5^{\prime}\right) ; \delta 6.39(1 \mathrm{H}$, $\mathrm{d}, J=2.4 \mathrm{~Hz}, \mathrm{H}-8) ; \delta 6.19(1 \mathrm{H}, \mathrm{d}, J=2.4 \mathrm{~Hz}$, H-6); $\delta 5.31(1 \mathrm{H}, \mathrm{d}, J=8 \mathrm{~Hz}, \mathrm{H}-1 ") ; \delta 3.61$ (1 H, m, H-5"); $\delta 3.55$ (1 H, m, H-4"); $\delta 3.51(1 \mathrm{H}$, 
m, H-2"); $\delta 3.47$ (1 H, m, H-3"). ${ }^{13}$ C-NMR (100 $\left.\mathrm{MHz}, \mathrm{CD}_{3} \mathrm{OD}\right): \delta 159.15(\mathrm{CH}, \mathrm{C}-2) ; \delta 135.92$ (C, C-3); $\delta 179.74$ (C, C-4); $\delta 163.23$ (C, C-5); $\delta 100.31(\mathrm{CH}, \mathrm{C}-6) ; \delta 166.91(\mathrm{C}, \mathrm{C}-7) ; \delta 95.06$ $(\mathrm{CH}, \mathrm{C}-8) ; \delta 158.80(\mathrm{C}, \mathrm{C}-9)$; $\delta 105.78(\mathrm{C}, \mathrm{C}-$ $10) ; \delta 122.84\left(\mathrm{C}, \mathrm{C}-1^{\prime}\right) ; \delta 132.63(\mathrm{CH}, \mathrm{C}-2$ ) $; \delta$ $116.34\left(\mathrm{CH}, \mathrm{C}-3^{\prime}\right) ; \delta 161.78\left(\mathrm{C}, \mathrm{C}-4{ }^{\prime}\right) ; \delta 116.34$ $\left(\mathrm{C}, \mathrm{C}-5^{\prime}\right) ; \delta 132.63\left(\mathrm{CH}, \mathrm{C}-6^{\prime}\right) ; \delta 104.33(\mathrm{CH}$, C-1"); 75.66 (CH, C-2"); $\delta 77.94$ (CH, C-3"); $\delta$ 73.55 (CH, C-4"); $\delta 77.23$ (CH, C-5"); $\delta 176.37$ (C, C-6").

$(2 R, 3 R)$-Taxifolin (2). Yellow crystals, m.p. $242^{\circ} \mathrm{C} .{ }^{1} \mathrm{H}-\mathrm{NMR}\left(400 \mathrm{MHz}, \mathrm{CD}_{3} \mathrm{OD}\right): \delta$ $4.94(\mathrm{~d}, 1 \mathrm{H}, J=12.0 \mathrm{~Hz}, \mathrm{H}-2) ; \delta 4.50(\mathrm{~d}, 1 \mathrm{H}, J=$ $12.0 \mathrm{~Hz}, \mathrm{H}-3$ ); $\delta 5.93$ (brs, $1 \mathrm{H}, \mathrm{H}-6$ ); $\delta 5.90$ (brs, $1 \mathrm{H}, \mathrm{H}-8) ; \delta 6.87$ (d, $\left.1 \mathrm{H}, J=8.0 \mathrm{~Hz}, \mathrm{H}-6^{\prime}\right)$; $\delta 6.82$ (d, $1 \mathrm{H}, J=8.0 \mathrm{~Hz}, \mathrm{H}-5$ '); $\delta 6.97$ (brs, $1 \mathrm{H}$, H-2'). ${ }^{13} \mathrm{C}-\mathrm{NMR}\left(100 \mathrm{MHz}, \mathrm{CD}_{3} \mathrm{OD}\right): \delta 85.16$ (CH, C-2); $\delta 73.88$ (CH, C-3); $\delta 198.67$ (C, C4); $\delta 164.72(\mathrm{C}, \mathrm{C}-5) ; \delta 97.44(\mathrm{CH}, \mathrm{C}-6) ; \delta$ 168.96 (C, C-7); $\delta 96.48$ (CH, C-8); $\delta 165.53$ (C, C-9); $\delta 102.09$ (C, C-10); $\delta 130.07$ (C, C$\left.1^{\prime}\right) ; \delta 116.08\left(\mathrm{CH}, \mathrm{C}-2^{\prime}\right) ; \delta 116.28\left(\mathrm{CH}, \mathrm{C}-5^{\prime}\right) ; \delta$ 147.35 (C, C-4'); $\delta 146.53$ (C, C-3'); $\delta 121.10$ $(\mathrm{CH}, \mathrm{C}-6$ ').

(+) Catechin (3). White needles, m.p. 175$176^{\circ} \mathrm{C} .{ }^{1} \mathrm{H}-\mathrm{NMR}\left(400 \mathrm{MHz}, \mathrm{CD}_{3} \mathrm{OD}\right): \delta 2.53(1$ $\mathrm{H}, \mathrm{dd}, J=16.1 \& 8.0 \mathrm{~Hz}, \mathrm{H}-4 \mathrm{~b}) ; \delta 2.85(1 \mathrm{H}$, $\mathrm{dd}, J=16.1 \& 8.0 \mathrm{~Hz}, \mathrm{H}-4 \mathrm{a}) ; \delta 3.98(1 \mathrm{H}, \mathrm{m}, \mathrm{H}-$ 3); $\delta 4.57(1 \mathrm{H}, \mathrm{d}, J=8.0 \mathrm{~Hz}, \mathrm{H}-2) ; \delta 5.93(1 \mathrm{H}$, d, $J=2.4 \mathrm{~Hz}, \mathrm{H}-6) ; \delta 5.86(1 \mathrm{H}, \mathrm{d}, J=2.4 \mathrm{~Hz}$, H-8); $\delta 6.72\left(1 \mathrm{H}, \mathrm{dd}, J=8.0 \& 1.8 \mathrm{~Hz}, \mathrm{H}^{\prime} 6^{\prime}\right) ; \delta$ $6.76\left(1 \mathrm{H}, \mathrm{d}, J=8.0 \mathrm{~Hz}, \mathrm{H}-5^{\prime}\right) ; \delta 6.83(1 \mathrm{H}, \mathrm{d}$, $\left.J=1.8 \mathrm{~Hz}, \quad \mathrm{H}-2^{\prime}\right) .{ }^{13} \mathrm{C}-\mathrm{NMR} \quad(100 \mathrm{MHz}$, $\left.\mathrm{CD}_{3} \mathrm{OD}\right): \delta 83.03(\mathrm{CH}, \mathrm{C}-2) ; \delta 68.89(\mathrm{CH}, \mathrm{C}-$ $3) ; \delta 28.70(\mathrm{CH}, \mathrm{C}-4) ; \delta 157.77(\mathrm{C}, \mathrm{C}-5) ; \delta$ $96.50(\mathrm{CH}, \mathrm{C}-6) ; \delta 157.11(\mathrm{C}, \mathrm{C}-7) ; \delta 95.71$ $(\mathrm{CH}, \mathrm{C}-8) ; \delta 158.02(\mathrm{C}, \mathrm{C}-9)$; $\delta 101.03(\mathrm{C}, \mathrm{C}-$ $10) ; \delta 132.41\left(\mathrm{C}, \mathrm{C}-1^{\prime}\right) ; \delta 115.46\left(\mathrm{CH}, \mathrm{C}-2^{\prime}\right) ; \delta$ 116.29 (CH, C-5'); $\delta 146.44$ (C, C-4'); $\delta 146.42$ (C, C-3'); $\delta 120.25$ (CH, C-6').

Mequilianin (quercetin-3-O-glucuronide) (4). Yellow amorphous powder. ${ }^{1} \mathrm{H}-\mathrm{NMR}$ (400 $\left.\mathrm{MHz}, \mathrm{CD}_{3} \mathrm{OD}\right): \delta 7.99$ (1 H, brs, $\left.\mathrm{H}-2^{\prime}\right) ; \delta 7.51$ $\left(1 \mathrm{H}, \mathrm{d}, J=8.0 \mathrm{~Hz}, \mathrm{H}-6^{\prime}\right) ; \delta 6.88(1 \mathrm{H}, \mathrm{d}, J=8.0$ Hz, H-5'); $\delta 6.40$ (1 H, brs, H-8); 6.21 (1 H, brs, $\mathrm{H}-6) ; \delta 5.36(1 \mathrm{H}, \mathrm{d}, J=8.0 \mathrm{~Hz}, \mathrm{H}-1 ") ; \delta 3.61$ (1 $\left.\mathrm{H}, \mathrm{m}, \mathrm{H}-5^{\prime \prime}\right) ; \delta 3.55$ (1 H, m, H-4"); $\delta 3.51(1 \mathrm{H}$, m, H-2"); $\delta 3.47$ (1 H, m, H-3"). ${ }^{13} \mathrm{C}-\mathrm{NMR}(100$ $\left.\mathrm{MHz}, \mathrm{CD}_{3} \mathrm{OD}\right): \delta 159.16(\mathrm{CH}, \mathrm{C}-2) ; \delta 135.72$ (C, C-3); $\delta 179.36$ (C, C-4); $\delta 163.03$ (C, C-5); $\delta 99.99(\mathrm{CH}, \mathrm{C}-6) ; \delta 166.27$ (C, C-7); $\delta 94.68$ $(\mathrm{CH}, \mathrm{C}-8) ; \delta 158.45$ (C, C-9); $\delta 105.62$ (C, C-
$10) ; \delta 122.67\left(\mathrm{C}, \mathrm{C}-1^{\prime}\right) ; \delta 116.11\left(\mathrm{CH}, \mathrm{C}-2^{\prime}\right) ; \delta$ 117.99 (CH, C-5'); $\delta 149.05$ (C, C-4'); $\delta 145.81$ $\left(\mathrm{C}, \mathrm{C}-3^{\prime}\right) ; \delta 122.67\left(\mathrm{CH}, \mathrm{C}-6^{\prime}\right) ; \delta 104.32(\mathrm{CH}$, $\mathrm{C}-1 ") ; \delta 75.58(\mathrm{CH}, \mathrm{C}-2 ") ; \delta 77.62(\mathrm{CH}, \mathrm{C}-3 ")$; $\delta 73.39(\mathrm{CH}, \mathrm{C}-4 ") ; \delta 78.10(\mathrm{CH}, \mathrm{C}-5 ") ; \delta$ 176.35 (C, C-6").

\section{Anti-inflammatory activity assay Chemicals}

The materials used for anti-inflammatory assay were HEK293 cells (Human embryonic kidney cells) (Thermo Fisher Scientific, Waltham, USA), Lipofectamine 2000 reagent (Thermo Fisher Scientific, Waltham, USA), Opti-MEM medium free from antibiotic (Thermo Fisher Scientific, Waltham, USA), Tumor Necrosis Factor- $\alpha$ human (TNF $\alpha$ ) (Sigma Aldrich, Louis, MO, USA), Thaw medium for assay (Sigma Aldrich, Louis, MO, USA) consisted of MEM medium (Hyclone, Thermo Fisher Scientific, Waltham, USA) supplemented with $10 \%$ FBS, $1 \%$ non-essential amino acids (Hyclone, Thermo Fisher Scientific, Waltham, USA), $1 \mathrm{mM}$ Na pyruvate (Hyclone, Thermo Fisher Scientific, Waltham, USA), and $1 \%$ Penicillin/Streptomycin (Hyclone, VWR, Radnor, PA, USA), Growth medium consisted of Thaw medium, and 50 $\mu \mathrm{g} / \mathrm{ml}$ of hygromycin B (Hyclone, VWR, Radnor, PA, USA). Also, $500 \mu 1$ (60 ng DNA/ $\mu \mathrm{l}$ ) of reporter (Component A) consisted of NF$\kappa \mathrm{B}$ luciferase reporter vector (BPS Biosciences, San Diego, CA, USA) and constitutively expressing Renilla luciferase vector (BPS Biosciences, San Diego, CA, USA), and $500 \mu \mathrm{l}$ (60 ng DNA/ $\mu \mathrm{l}$ ) of negative control reporter (Component B) consisted of non-inducible luciferase vector (BPS Biosciences, San Diego, CA, USA), and constitutively expressing Renilla luciferase vector (BPS Biosciences, San Diego, CA, USA) were used. Luciferase assay reagent (Azure biosystem, Dublin, CA, USA) was also used in the protocol.

\section{Determination of the dose response of HEK293 cells transfected with NF-кB reporter to $\mathrm{TNF} \alpha$}

The procedure in generalized transfection and assay protocols were previously described $^{17}$. Briefly, the HEK293 cells were suspended in a 96 well plate containing $100 \mu \mathrm{l}$ growth medium in each well at a density of 30,000 cells per well, and incubated for $24 \mathrm{hrs}$. The DNA mixture (Reporter component A) 
was diluted by Opti-MEM medium (antibioticfree) (1:15) with gentle shaking. Also, the dilution of $0.35 \mu$ lipofectamine 2000 with 15 $\mu 1$ of Opti-MEM medium (antibiotic-free) was performed with the incubation for $5 \mathrm{~min}$. at room temperature. After that, the diluted DNA mixture was gently mixed with the diluted lipofectamine 2000, and the whole mixture was incubated for $25 \mathrm{~min}$. at room temperature. The DNA-Lipofectamine 2000 mixture $(30 \mu \mathrm{l})$ was added to each well. The 96 well plate was incubated at $37^{\circ} \mathrm{C}$ in a $\mathrm{CO}_{2}$ incubator for 24 hrs, to carry out the dual luciferase assay. Both firefly luminescence and Renilla luminescence were measured by using a luminometer.

\section{RESULTS AND DISCUSSION}

Structure elucidation of compounds 1-4 isolated from ethyl acetate fraction of $C$. polygonoides

The structural elucidation of the isolated compounds (1-4) (Fig. 1) was based on spectroscopic analyses $\left({ }^{1} \mathrm{H} \quad \& \quad{ }^{13} \mathrm{C}-\mathrm{NMR}\right)$ compared with the data published in the literatures. The compounds were identified as kaempferol-3-O- glucuronide $(\mathbf{1})^{18},(2 R, 3 R)$ taxifolin $(\mathbf{2})^{19 \& 20},(+)$ catechin $(\mathbf{3})^{21 \& 22}$ and mequilianin $(\mathbf{4})^{18}$. Compounds $(\mathbf{1 - 3})$ were previously reported to be isolated from the leaves of the plant under investigation ${ }^{3}$.<smiles>O=C1c2c(O)cc(O)cc2OC(c2ccc(O)c(O)c2)C1O</smiles>

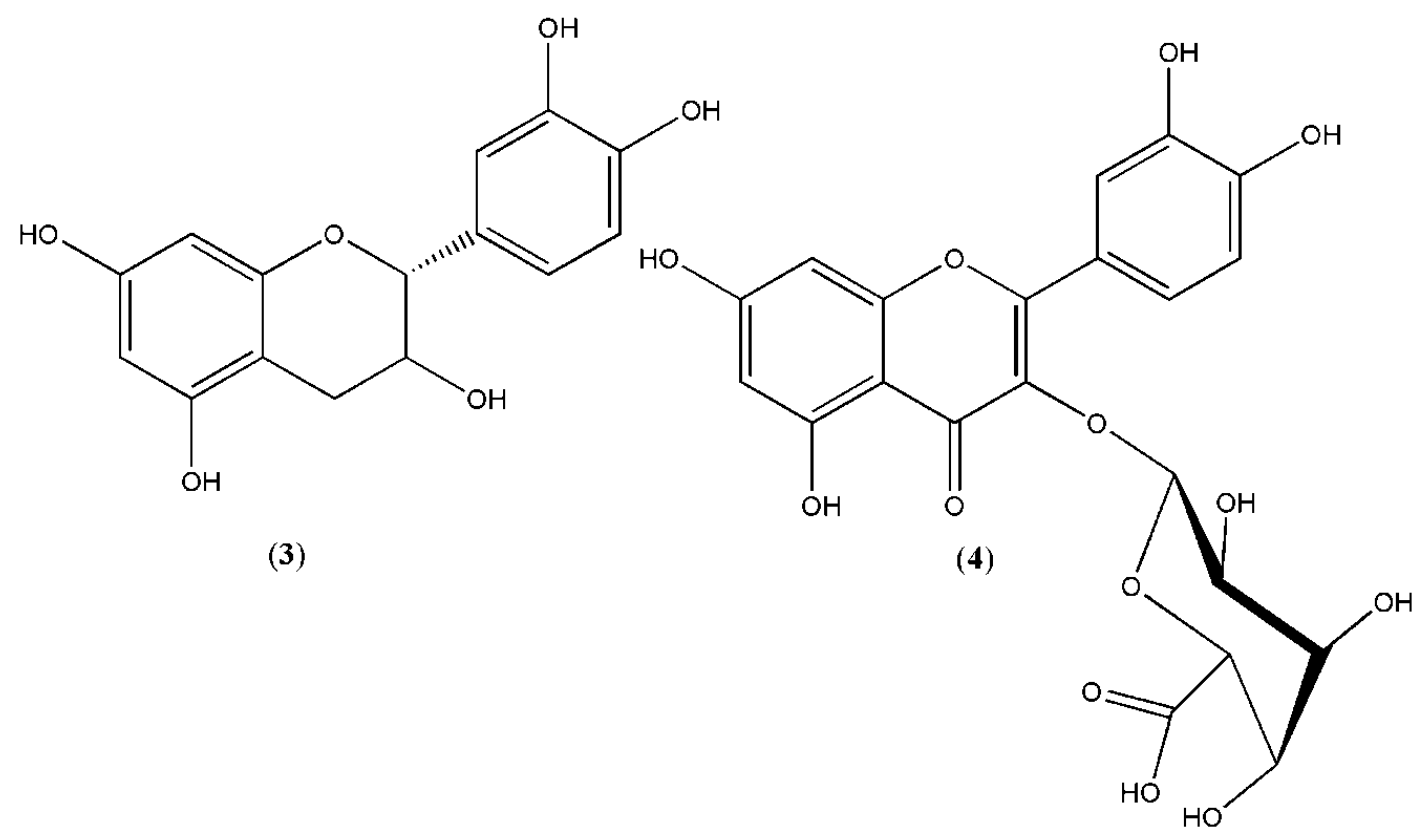

Fig. 1: List of isolated compounds (1-4). 


\section{Anti-inflammatory activity of the isolated compounds through the inhibition of NF- $\mathrm{KB}$ pathway}

Previous reported biological studies of our plant under investigation revealed the antiinflammatory activity of methanolic extract of the leaves and its ability to exert reduction in the oxidative stress induced by haloperidol ${ }^{5}$. This scientific basic corresponding was augmented in our study through the assessment of the anti-inflammatory activity of the plant methanolic and ethyl acetate extract, together with the isolated compounds (1-4) through the inhibition of the NF- $\mathrm{BB}$ pathway induced by $\alpha$ TNF. Both the methanolic and ethyl acetate extracts, together with the isolated flavonoids
(1-4) exhibited potent anti-inflammatory activity through the inhibition of NF- $\mathrm{BB}$ translocation pathway (Table 1 and Fig. 2). Calligonum polygonoides L. subsp. comosum aerial part methanol extract showed significant anti-inflammatory activity against NF- $\kappa \mathrm{B}$ translocation in comparison to bortezomib which was used as a positive control. The phytochemical study of the bioactive ethyl acetate fraction led to isolation of four NF- $\kappa \mathrm{B}$ inhibitors. Kaempferol-3-O- glucuronide (1) and mequilianin (4) are first reported as NF- $\mathrm{KB}$ inhibitors. Taxifolin (2), and $(+)$ catechin $(3)$ have been reported to display antiinflammatory activity through inhibition of NF$\kappa B$ mechanism $^{16,23-26}$.

Table 1: The inhibitory effect of the isolated compounds (1-4) on NF-kB release.

\begin{tabular}{|c|c|}
\hline Compound & NF- $\kappa B / \mathrm{IC}_{50}(\mu \mathrm{g} / \mathrm{mL})$ \\
\hline Ethyl Acetate fr. & $18.37 \pm 0.40$ \\
\hline Methanol fr. & $10.14 \pm 0.22$ \\
\hline Kaempferol-3-O- glucuronide (1) & $2.19 \pm 0.04$ \\
\hline Taxifolin (2) & $6.41 \pm 0.14$ \\
\hline Catechin (3) & $3.08 \pm 0.06$ \\
\hline Mequilianin (4) & $3.91 \pm 0.08$ \\
\hline Bortezomib* & $2.79 \pm 0.06$ \\
\hline
\end{tabular}

*Reference compound.

Values are displayed as means \pm S.D., $n=3$.

1Y: Kaempferol-3-O- $\beta$-D-glucuronide (1), 1R: Taxifolin (2), 2R: (+) Catechin (3), 2Y: Mequilianin (4), ET: Ethyl acetate fraction, ME: Methanol extract, Bortezomib reference compound.

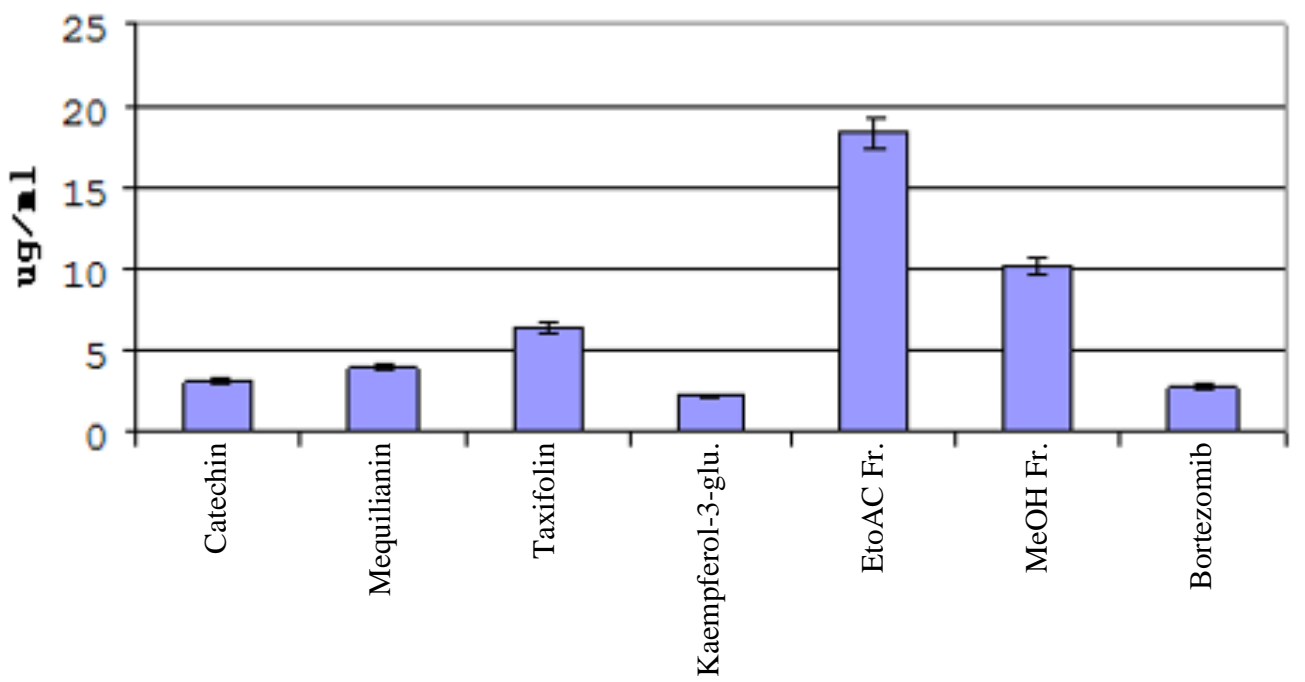

Fig. 2: The inhibitory effect of the isolated compounds (1-4) on NF- $\kappa$ B release. 


\section{Conclusion}

The aerial parts methanol extract and ethyl acetate fraction of $C$. polygonoides showed for the first time inhibition of NF- $\kappa B$ translocation. From the ethyl acetate fraction, four potent anti-inflammatory flavonoids (1-4) were isolated. The isolated flavonoids were identified by NMR spectral techniques and confirmed by comparing with previously reported data. Flavonoid glycoside, kaempferol-3- $O-\beta$-D-glucuronide (1) exhibited the most potent activity similar to bortezomib (positive control) with $\mathrm{IC}_{50}=2.78 \pm 0.06 \mu \mathrm{g} / \mathrm{mL}$. Based on our findings, $C$. polygonoides extract is recommended as a valuable food supplement for treatment of vascular inflammation conditions; cardiovascular diseases, and Alzheimer.

\begin{tabular}{|c|c|}
\hline \multicolumn{2}{|c|}{ List of abbreviations } \\
\hline $\mathrm{NF}-\kappa \mathrm{B}$ & Nuclear Factor-Kappa \\
\hline HEK293 cells & $\begin{array}{l}\text { Human embryonic kidney } \\
\text { cells }\end{array}$ \\
\hline $\mathrm{IC}_{50}$ & $\begin{array}{l}\text { The half maximal inhibitory } \\
\text { concentration }\end{array}$ \\
\hline $\mathrm{L}$ & Litre \\
\hline $\mathrm{Kg}$ & Kilogram \\
\hline$\mu \mathrm{M}$ & Micro-molar \\
\hline$\mu \mathrm{g}$ & Microgram \\
\hline $\mathrm{ml}$ & Milliliter \\
\hline$\mu 1$ & Microliter \\
\hline
\end{tabular}

\section{Declarations}

The authors have no conflict of interest. The author(s) declared that no grants were involved in supporting this work.

\section{Acknowledgements}

The authors are thankful to Dr. Ahmed M. Fareed, Associate professor of plant taxonomy, Department of Botany, Faculty of Science, Assuit University for the identification of the plant under study.

\section{REFERENCES}

1- S. Zouari, A. Dhief, S. and Aschi-Smiti, "Chemical composition of essential oils of Calligonum comosum cultivated at the south-eastern of Tunisia: A comparative study between flowering and fructification stages", J. Essent. Oil. Bear. Pl., 15, 320327 (2012).
2- S. Bewal, S. K. Sharma, A. Parida, S. Shivam, S. R. Rao and A. Kumar, "Utilization of RAPD marker to analyze natural genetic variation in Calligonum polygonoides L. A key stone species of Thar desert", Int. J. Integr. Biol., 5, 148151 (2009).

3- H. Ahmed, A. Moawad, A. Owis, S. AbouZid and O. Ahmed, "Flavonoids of Calligonum polygonoides and their cytotoxicity", Pharm. Biol., 54, 21192126 (2016).

4- I. Pervaiz, H. Saleem, M. Sarfraz, M. I. Tousif, U. Khurshid, S. Ahmad, G. Zengin, K. I. Sinan, M. Locatelli and F. M. Mahomoodally, "Multidirectional insights into the phytochemical, biological, and multivariate analysis of the famine food plant (Calligonum polygonoides L).: A novel source of bioactive pshytocompounds", Food Res. Int., 137, 109606 (2020).

5- E. A. Abdel-Sattar, S. M. Mouneir, G. F. Asaad and H. M. Abdallah, "Protective effect of Calligonum comosum on haloperidol-induced oxidative stress in rat", Toxicol. Ind. Health, 30, 147-153 (2014).

6- L. Sabry, M. A. Sattar, H. A. Amin and E. A., Sattar, "Antiosteoporotic effect of some herbal extracts versus alendronate on an animal model of osteoporosis", Life Sci. J., 10, 177-187 (2013).

7- X. Liu, M. Zakaria, M. Islam, R. Radhakrishnan, A. Ismail, H. Chen, K. Chan and A. Al-Attas, "Anti-inflammatory and anti-ulcer activity of Calligonum comosum in rats", Fitoterapia, 72, 487491 (2001).

8- Z. El-Hawary and T. Kholief, "Biochemical studies on some hypoglycemic agents (II) effect of Calligonum comosum extract" Arch. Pharmacal. Res., 13, 113 (1990).

9- M. Q. Samejo, S. Memon, M. I. Bhanger and K. M. Khan, "Essential oil constituents in fruit and stem of Calligonum polygonoides", Ind. Crops Prod., 45, 293-295 (2013).

10- F. K. Swirski and M. Nahrendorf, "Leukocyte behavior in atherosclerosis, myocardial infarction, and heart failure", Science, 339, 161-166 (2013). 
11- S. Purkayastha, G. Zhang and D. Cai, "Uncoupling the mechanisms of obesity and hypertension by targeting hypothalamic IKK- $\beta$ and NF-kB", Nat. Med., 17, 883 (2011).

12- X. Li, Y. Dai, S. Yan, Y. Shi, B. Han, J. $\mathrm{Li}$, L. Cha and J. Mu "Down-regulation of lncRNA KCNQ1OT1 protects against myocardial ischemia/reperfusion injury following acute myocardial infarction", Biochem. Biophys. Res. Commun., 491, 1026-1033 (2017).

13- B. Pamukcu, G. Y. Lip and S. E. hantsila, "The nuclear factor-kappa B pathway in atherosclerosis: A potential therapeutic target for atherothrombotic vascular disease", Thromb. Res., 128, 117123(2011).

14- M. T. Heneka, M. J. Carson, J. El Khoury, G. E. Landreth, F. Brosseron, D. L. Feinstein, A. H. Jacobs, T. Wyss-Coray, J. Vitorica, and R. M. Ransohoff, "Neuroinflammation in Alzheimer's disease", Lancet Neurol., 14, 388-405 (2015).

15- N. Karunaweera, R. Raju, E. Gyengesi and G. Münch, "Plant polyphenols as inhibitors of NF-kB induced cytokine production - a potential anti-inflammatory treatment for Alzheimer's disease?" Front. Mol. Neurosci., 8, 24 (2015).

16- K. W. Choy, D. D. Murugan, X. F. Leong, R. Abas and A. Alias, "Flavonoids as natural anti-inflammatory agents targeting nuclear factor-kappa $\mathrm{B}(\mathrm{NF \kappa B})$ signalling in cardiovascular diseases: A mini review", Front. Pharmacol., 10, 12951303 (2019).

17- P. A. Baeuerle, "Pro-inflammatory signaling: Last pieces in the NF- $\mathrm{kB}$ puzzle?", Curr. Biol., 8, 19-22 (1998).

18- K. Price, I. Colquhoun, K. Barnes and M. Rhodes, "Composition and content of flavonol glycosides in green beans and their fate during processing", J. Agric. Food Chem., 46, 4898-4903 (1998).

19- S. Akiyo, O. Kosei, C. Makusut, S. Kohichi and O. Kazue, "Separation and Identification of Taxifolin 3-O-Glucoside
Isomers from Chamaecyparis Obtusa (Cupressaceae)", Nat. Prod. Lett., 16 (6), 383-387 (2002).

20- M. V. Bahia, J. P. David and J. M. David, "Occurrence of biflavones in leaves of Caesalpinia pyramidalis specimens", Quim. Nova, 33, 1297-1300 (2010).

21- W. Jin and P. F. Tu, "Preparative isolation and purification of trans-3,5,4'trihydroxystilbene-4'-O- $\beta$-d-gluco-

pyranoside and (+) catechin from Rheum tanguticum Maxim. ex Balf. using highspeed counter-current chromatography by stepwise elution and stepwise increasing the flow-rate of the mobile phase", $J$. Chromatogr. A, 1092, 241-245 (2005).

22- M. H. Abdel-Razek,"NMR Assignments of Four Catechin Epimers", Asian J. Chem., 19 (6), 4867-4872 (2007).

23- J. Chen, X. Sun, T. Xia, Q. Mao and L. Zhong, "Pretreatment with dihydroquercetin, a dietary flavonoid, protected against concanavalin A-induced immunological hepatic injury in mice and TNF- $\alpha$ /ActD-induced apoptosis in HepG2 cells", Food Funct., 9, 2341-2352 (2018).

24- J. Y. Park, M. S. Lim, S. I. Kim, H. J. Lee, S. S. Kim, Y. S. Kwon and W. Chun, "Quercetin-3-O- $\beta$-D-glucuronide

suppresses lipopolysaccharide-induced JNK and ERK phosphorylation in LPSchallenged RAW264. 7 cells", Biomol. Ther. (Seoul), 24, 610-615 (2016).

25- P. A. Ruiz, A. Braune, G. Ho"lzlwimmer, L. Quintanilla-Fend and D. Haller, "Quercetin inhibits TNF-induced NF- $\mathrm{BB}$ transcription factor recruitment to proinflammatory gene promoters in murine intestinal epithelial cells", $\boldsymbol{J}$. Nutr., 137, 1208-1215 (2007).

26- S. S. Syed Hussein, M. N. A. Kamarudin and H. Abdul Kadir, "(+)-Catechin attenuates NF- $\kappa \mathrm{B}$ activation through regulation of Akt, MAPK, and AMPK signaling pathways in LPS-induced BV-2 microglial cells", Am. J. Chinese Med., 43, 927-952 (2015). 


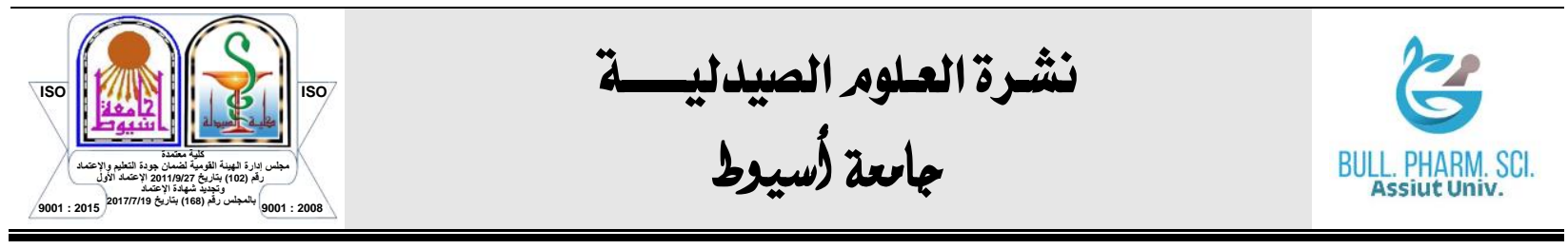

\title{
تقيم المستخلصات والفلافونوديات المعزولة من نبات كاليجونم بلوجنويلي كمضادات للألتهابات
}

\author{
أحمد محمد زاهز - مي عبدالهادي محمد احمد - نسمة مصطفى محمد \\ قسم العقاقير ، كلية الصيدله ، جامعة أسيوط ، أسيوط ، مصر
}

كاليجونم بلوجنويدي هو نبات يتبع فصيلة الأرطاه التابعة للعائلة البطاطية ، وهي شجيرة برية

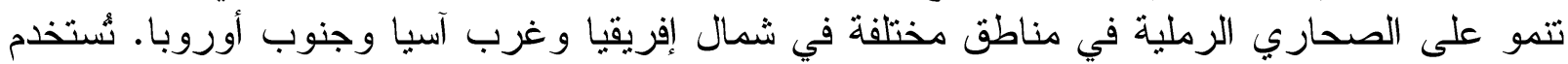

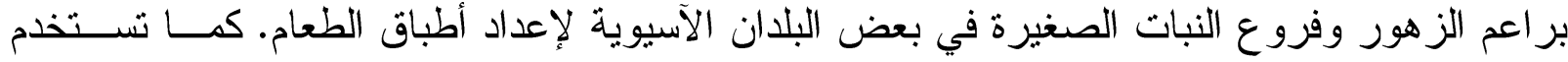

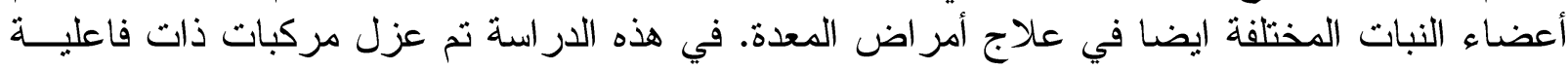

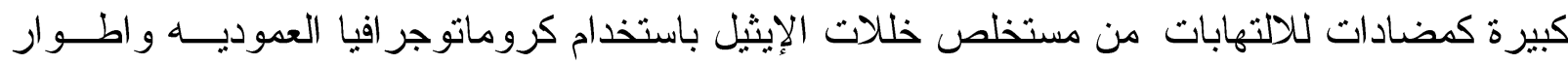

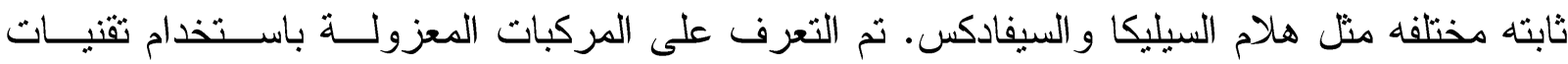

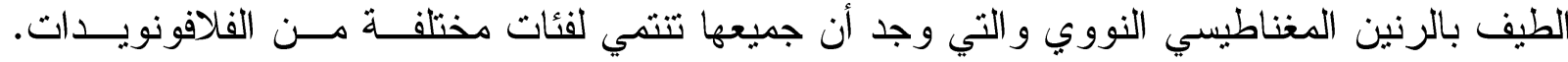

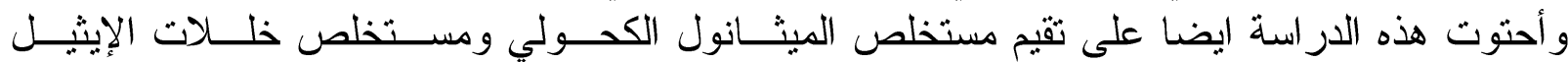

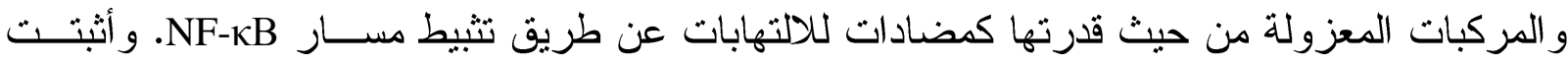

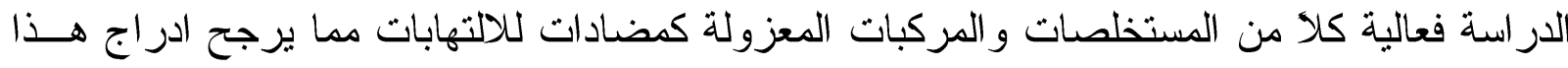
النبات تحت المغذيات الو اعدة لعلاج اضطربات المات الاوعية الدموية. 